UDC 577.21

\title{
A review on microcephaly genes
}

\author{
S. Shahid, S. Irshad \\ Institute of Biochemistry and Biotechnology, University of the Punjab \\ Lahore, Pakistan \\ saba.ibb@pu.edu.pk
}

\begin{abstract}
This review aims to summarize the recent findings regarding microcephaly genes. We have discussed the molecular genetics studies of microcephaly genes including a comprehensive appraisal of the seven mapped loci (MCPH1-MCPH7), their corresponding genes and protein products of the genes, their likely role in normal brain development and the details of the mutations reported in these genes.
\end{abstract}

Keywords: microcephaly, MCPH loci, MCPH gene, mutation, neurogenesis.

Introduction. Microcephaly is a neurological disorder [1] defined as a small cranium with a significantly reduced head circumference (HC) of more than two standard deviations (SD) [2, 3]. Microcephaly can occur with congenital (primary) or postnatal (secondary) onset, and is caused by genetic or non-genetic factors $[4,5]$. Autosomal recessive primary microcephaly is characterized by non-progressive mild-to-moderate mental retardation and a substantial reduction in prenatal human brain growth without alteration of the cerebral architecture [6-9]. It is a model disease to study human neurogenesis [10]. Secondary, microcephaly is a disorder in which the brain is of the expected size at birth but subsequently fails to grow normally. The condition occurs due to mutations in an apparently ubiquitously expressed X-linked gene $\mathrm{MeCP} 2$ which has a crucial role in maintaining the mature neuronal state [11]. The incidence is 1 in 10000 in consanguineous populations, less in non-consanguineous populations [7].

Microcephaly genes. Clinical surveys from the 1950s and earlier suggested that microcephaly was likely to be an autosomal recessive Mundelein disorder. However, molecular studies of this disorder were performed in the late 1990's [12]. Microcephaly exhibits genetic heterogeneity, having been associated with mu-

(C) Institute of Molecular Biology and Genetics, NAS of Ukraine, 2012 tations in seven microcephaly loci. These loci, known as «microcephaly genes», are, therefore, presumed to play important roles in size regulation during brain development [13]. So far, seven genetic loci (MCPH1-7) for microcephaly have been mapped [14]. Genetic causes of microcephaly subtypes $1-7$ include mutations in genes encoding microcephalin (MCPH1) [15], WDR62 (MCPH2) [8], CDK5RAP2 (MCPH3) [16], CEP152 (MCPH4) [39], ASPM (MCPH5) [17], CENPJ (MCPH6) [16], STIL (MCPH7) [18]. A detailed description of the MCPH gene mutations and their most likely functions in the development of microcephaly is as follows (Table 1).

Microcephalin (MCPH1). Microcephalin (MCPH1) is an 835 amino acid protein containing BRCA1 C-terminal (BRCT) domains. $M C P H 1$ gene in chromosome locus 8p23 contains 14 exons, the genomic size is $241905 \mathrm{bp}$ with three isoforms reported so far and 8032 bp Open Reading Frame (ORF) [15]. The mutations identified earlier were truncating mutations and, therefore, were predicted to lead to a complete loss of the gene function [19]. Jackson and colleagues has refined the $\mathrm{MCPH1}$ region from $13 \mathrm{cM}$ to $2.1 \mathrm{Mb}$. In two consanguineous families of northern Pakistani origin, a single homozygous 74CG (S25X) non-sense mutation was identified in the second exon of a 2.505 nucleotide, 14 exon of uncharacterized gene [15] (Figure, $a$ ) which encodes the protein microcephalin, also is referred to as 
Table 1

Microcephaly genes

\begin{tabular}{|c|c|c|c|c|c|c|c|}
\hline Locus & OMIM & $\begin{array}{l}\text { Map } \\
\text { location }\end{array}$ & Gene & Protein & $\begin{array}{l}\text { Centrosome (C) } \\
\text { or spidle pole } \\
\text { (SP) association }\end{array}$ & $\begin{array}{l}\text { DNA dama- } \\
\text { ge response }\end{array}$ & Function \\
\hline MCPH1 & $\begin{array}{l}251200 \\
607117\end{array}$ & $8 \mathrm{p} .23$ & MCPH1 & Microcephalin & Yes (C) & Yes & $\begin{array}{l}\text { DNA damage repair; Chromosome } \\
\text { condensation; Transcriptional regulation } \\
\text { of DNA damage genes }\end{array}$ \\
\hline $\mathrm{MCPH} 2$ & $\begin{array}{l}604317 \\
613583\end{array}$ & $19 \mathrm{q} 13.12$ & WDR62 & WDR62 & Yes (SP) & ND & Cortical lamination, neural migration \\
\hline МCPH3 & $\begin{array}{l}604804 \\
608201\end{array}$ & $9 q 33.3$ & CDK5RAP2 & CDK5RAP2 & Yes (C) & Yes & $\begin{array}{l}\text { Predicted role in regulating; microtubule } \\
\text { dynamics; centrosome maturationand } \\
\text { cohesion }\end{array}$ \\
\hline MCPH4 & $\begin{array}{l}604321 \\
613529\end{array}$ & $15 \mathrm{q} 21.1$ & CEP152 & CEP152 & Yes $(\mathrm{C})$ & Yes & Neural development \\
\hline MCPH5 & $\begin{array}{l}608716 \\
605481\end{array}$ & $1 \mathrm{q} 31$ & $A S P M$ & ASPM & Yes (SP) & Yes & Spindle pole organization and orientation \\
\hline МCPH6 & $\begin{array}{l}608393 \\
609279\end{array}$ & $13 q 12.2$ & CENPJ & CENPJ & Yes $(C)$ & ND & $\begin{array}{l}\text { Centriole biogenesis and length; } \\
\text { microtubule dynamics }\end{array}$ \\
\hline МCPH7 & $\begin{array}{l}612703 \\
181590\end{array}$ & $1 \mathrm{p} 32$ & $S T I L$ & STIL & Yes (SP) & ND & Spindle organisation; Hh/Shh signalling \\
\hline
\end{tabular}

ND: not determined; OMIM: OnlineMendelian Inheritance in Man (http://www.ncbi.nlm.nih.gov/omim) number [7, 67].

BRIT1 for BRCT Repeat Inhibitor of $h$ Tert expression [20]. Later, the mutation in this gene was reported at disorder of microcephaly, short stature and misregulated chromosome condensation, known as Premature Chromosome Condensation Syndrome (PCC). It was therefore discovered that both MCPH1 and PCC syndrome are allelic disorders originated from mutations within the same gene [21]. A missense mutation has been reported in $\mathrm{MCPH1}$ gene demonstrating less severe cellular phenotype and mild microcephaly [22]. Also, a large deletion mutation encompassing first 6 exons of Microcephalin gene in an Iranian family, showing autosomal recessive mental retardation and mild microcephaly, has been reported [23]. Loss of function mutations in the genes associated with $\mathrm{MCPH}$ reduced human brain size by about two-thirds, without producing gross abnormalities in brain organization or physiology [24]. RNA interference (RNAi) of MCPH1 has implicated the corresponding protein as a DNAdamage response protein that regulates the transcription of Chkl and BRCAl, two genes involved in the response to DNA damage. MCPH1 has a function downstream of Chk1 in the ATR-signalling pathway. MCPH1 also plays an ATR-independent role in maintaining inhibitory Chk1 phosphorylation, which prevents premature entry into mitosis [25]. Farooq et al. described the Craniosynostosis-Microcephaly with Chromosomal Breakage (CMCB) and other abnormalities that were caused by a truncating mutation (302CG) in exon 4 of the MCPH1 gene. CMCB is found to be allelic to PCC syndrome and MCPH1 [26]. Most reported mutations induce the production of non-functional, truncated proteins [2]. Microcephalin has a role in DNA damage response $[27,28]$ and regulation of cell cycle checkpoints [29]. It has been proposed that mutations in microcephalin are a causal link between impaired DNA damage response signaling and microcephaly and that misregulated chromosome condensation in MCPH1 is mediated by condensin II protein [30, 31]. It has been demonstrated that microcephalin protein is recruited to double-strand breaks via interaction of its C-terminal BRCT domains with phosphorylated H2AX, 

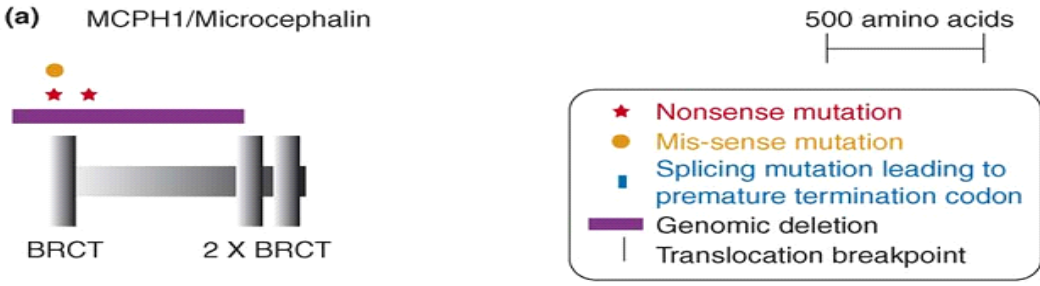

(b) MCPH5/ASPM

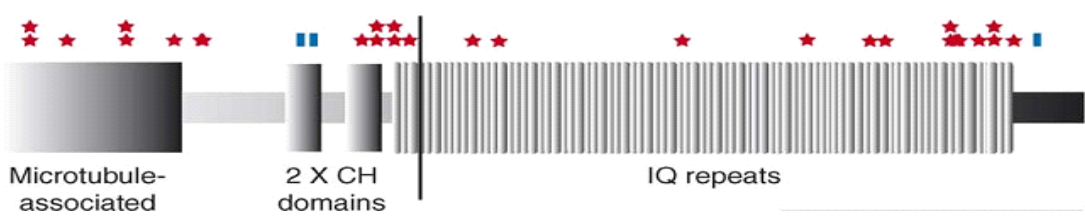

Mutations reported in $(a) \mathrm{MCPH} 1$ and $(b)$ ASPM. A micro deletion that includes the promoter region and first nine exons of MCPH1 is indicated by a horizontal line. The translocation break point in the ASPM gene is depicted by a vertical line. Recurrent mutations are denoted by an additional star [12]

a histone variant that marks sites of damaged DNA, further expanding the signal to Chk1 and Chk2 via subsequent phosphorylation, leading to the modulation of cell cycle, DNA repair and apoptosis [31].

WDR62 (MCPH2). WDR62 gene was identified as the second most common cause of MCPH after finding homozygous missense and frame-shifting mutations in seven MCPH families [8]. The gene lies within the $\mathrm{MCPH} 2$ candidate linkage interval at chromosome $19 \mathrm{q} 13.12$ with 32 functional exons and genomic size of $50230 \mathrm{bp}$ [21]. The gene has two predicted isoforms and the protein consisting of 1523 residues contains 15 WD repeats. In three recently published research articles, authors have found six different homozygous recessive mutations in human WDR62 showing linkage at $\mathrm{MCPH} 2$ locus [8, 33, 34]. Interestingly, four of them were missense mutations. Like other $\mathrm{MCPH}$ proteins overexpressed WDR62 was localized to the spindle poles during mitosis. In contrast, a mutant WDR62 protein, carrying one of the causative missense alterations, p.Arg438His, failed to localize in the spindle poles during mitosis [8]. Bilguvar et al. have found 5 homozygous WDR62 mutations including deletions and premature terminations in patients suffering from microcephaly and some additional phenotypes, belonging to Turkish origin [33]. WDR62 missense mutations might impair the centrosomal function of WDR62, whereas, on the other hand, a complete loss of WDR62 function might affect severely neuronal migration as well. Taken together, the current studies strongly suggested a function for WDR62 in proliferation and spindle formation, as well as in neuronal migration, thereby showing a com- mon mechanism underlying primary microcephaly and malformations of cortical development [5]. Yu et al. also identified six families with syndrome of congenital microcephaly and diverse defects in cerebral cortical architecture. They identified six mutations in WDR62 gene by use of targeted high throughput sequence analysis [34]. Nuclear localization of WDR62 in human neurons that had just migrated to the cortical plate was also observed which suggested that WDR62 might play an important role in cortical lamination as well [8].

CDK5RAP2 (MCPH3). The cyclin dependent kinase 5 regulatory subunit-associated protein 2 is a protein that in humans is encoded by the CDK5RAP2 gene, also referred to as the centrosome associated protein 215 (CEP215) or the CDK5 activator binding protein C48 (C48).

Four isoforms have been reported so far. The human full length, 1893 amino acid CDK5RAP2 protein contains an N-terminal interaction site with the gamma tubulin ring complex (gTuRC), a C-terminal interaction site with CDK5 regulatory subunit1 lines and tumors, and its increased expression is positively associated with proliferation of glio blastoma cells $[2,35]$. The $\mathrm{MCPH} 3$ locus was refined from $12 \mathrm{cM}$ to $2.2 \mathrm{Mb}$ by the identification from a family of northern Pakistani origin [16]. The gene contains 38 exons; genomic size is 191290 bp, with 5682 bp ORF [2, 16, 36]. Multiple transcript variants exist for this gene on chromosome 9q33.2, but the complete molecular mechanism for only two has been determined [14]. A homozygous 243T $\rightarrow \mathrm{A}$ (S81X) nonsense mutation and an intronic mutation 15 bases prior to the normal splice acceptor sequence 
IVS26-15AG (E385fsX4) were identified. Both mutations are segregated from the disease within the families and were not present in 1380 control alleles. The intronic mutation created a new, superior splice acceptor site in exon 27 , leading to the addition of four new amino acids and a termination codon [16].

Hassan et al. described a previously known mutation (S81X) in MCPH family from Northern Pakistan and concluded that the exact nomenclature for this mutation was 246T $\rightarrow$ A (Y82X) [37]. Zhang et al. demonstrated that CDK5RAP2 is required for spindle checkpoint regulation. They found that loss of its function leads to chromosome mis-segregation and reduced expression of spindle checkpoint proteins, via interaction with their promoters and transcription regulation [38].

CEP152 (MCPH4). Guernsey et al. have discovered both homozygous and heterozygous mutations in CEP152 gene located within MCPH4 linkage locus at chromosome $15 \mathrm{q} 21.1$ in two Canadian families with MCPH using single nucleotide polymorphism (SNP)based genome scan. However, in mice, they were able to generate a cDNA clone product of the correct size spanning exons $21-24$ of the mouse CEP152 ortholog by using RNA extracted from mouse brain tissue; cDNA could be readily detected in stage 12.5 and 14.5 embryonic brains. They have also used tools of bioinformatics to elaborate the pathogenic effect of homozygous mutation in CEP152 gene (Q265P) in two MCPH4 linked families [39]. Blachon et al. have demonstrated that Asl (ortholog of CEP152 in Drosophila) is a conserved gene required for ciliogenesis; which is involved in the initiation of centriole duplication and that it is dispensable for pericentriolar material (PCM) recruitment in meiosis in MC centrioles (Mother Centrioles). They were successful to show that $A s l$ is essential for centriole formation in brain cells [40]. A homozygous MCPH-causing mutation was reported in human CEP63. CEP63 forms a complex with another $\mathrm{MCPH}$ protein, CEP152, a conserved centrosome duplication factor. Together, these two proteins are essential for maintaining normal centrosome numbers in cells. Using super-resolution microscopy, it was found that CEP63 and CEP152 co-localize in a discrete ring around the proximal end of the parental centriole, a pattern specifically disrupted in CEP63-deficient cells derived from patients with $\mathrm{MCPH}$. This work suggests that the CEP152-CEP63 ring-like structure ensures normal neurodevelopment and that its impairment particularly affects human cerebral cortex growth [9].

ASPM (MCPH5). The most common cause of $\mathrm{MCPH}$ is homozygous mutations in the MCPH5 gene [41] (Figure, $b$ ), Abnormal Spindle-like, Microcephaly associated gene $(A S P M)[17,42-45]$. ASPM is a very large protein of 3477 amino acids comprising a putative microtubule-binding domain at its N-terminal [46, 47], a calponin homology domain, multiple IQ calmodulin binding domains $[46,48]$ and a carboxy terminal region with no identifiable domains [19, 48, 49]. ASPM is a large gene with 28 exons and a 10.4-kb ORF. The 24 published $A S P M$ mutations comprise nonsense mutations, deletions of 1-7 base pairs, a break point translocation, and intronic splice-donor point mutations [42-45]. The mutations are distributed throughout the gene and are all predicted to produce truncated protein products ranging in size from 116 amino acids to 3,357 amino acids $[42,43]$. It has been suggested that the common mechanism of action of $A S P M$ mutation is nonsense-mediated mRNA decay [50] Nonsense-mediated mRNA decay is a mechanism that selectively degrades mRNAs harboring premature termination (nonsense) codons [72]. ASPM hampers symmetric cell division of neural progenitors [51]. It has been suggested that a second gene causing MCPH exists at the MCPH5 locus, as mapping studies in five Jordanian and Dutch families linked the families to the MCPH5 locus but excluded the genetic region containing ASPM [52]. Sadi et al. identified heterozygous $A S P M$ mutations in three Algerian siblings born to consanguineous parents of which two were nonsense and frameshift mutations predicting a loss of function either by nonsense-mediated mRNA decay or by synthesis of a severely truncated and presumably inactive ASPM protein. ASPMrelated MCPH is associated with simplified cortical gyration [32]. The function of the ASPM protein in neural progenitor cell expansion, as well as its localization to the mitotic spindle and mid body, suggested that it regulates brain development by a cell division-related mechanism [49]. In some recent studies, expression of $A S P M$ in cancer cells has been investigated. $A S P M$ has been found down-regulated in ionizing-radiation treated cells [53] and its down-regulation has shown to decrea- 
se the Brcal protein expression as well [54]. ASPM plays a role in mitotic spindle function including orientation of cleavage plane. The spindle apparatus dictates the plane of cell cleavage, which is critical in the choice between symmetric or asymmetric division [55].

CENPJ (MCPH6). The human centromeric protein $\mathrm{J}$ encoded by gene CENPJ, also referred to as centrosomal P4.1-associated protein (CPAP), LAG-3-associated protein (LAP) or LYST-interacting protein1 (LIP1). The human full length CENPJ protein of 1338 amino acid contains a 112-amino acid long microtubule destabilizing motif PN2-3 [56] and two C-terminal 14-3-3 binding sites [57]. The CENPJ gene (MIM 609279) spans 40672 bp with 5187 bp ORF. Four mutations have been reported in this gene so far. Initially two mutations were reported in three families [16] including two families from Northern Pakistan having one mutation and other from Brazil with second mutation within a previously identified locus on human chromosome 13q12.2 [58]. The 6-Mb MCPH6 region was refined by the use of novel polymorphic microsatellite markers that were genotyped in the original Brazilian family used to map the locus and in two additional northern $\mathrm{Pa}$ kistani affected consanguineous families [16]. This facilitated the reduction of the locus to $3.1 \mathrm{Mb}$ and enabled the selection of CENPJ gene in which two homozygous mutations were identified: the frameshift mutation $17 \mathrm{del}$ Cin exon 2 (T6fsX3), in two pedigrees, and the missense mutation $3704 \mathrm{~A} \rightarrow \mathrm{T}$ in exon $16(\mathrm{E} 1235 \mathrm{~V})$, in one pedigree. $3704 \mathrm{~A} \rightarrow \mathrm{T}$ is the only MCPH mutation described that is not predicted to result in a protein truncation. The E1235V mutation occurs in a highly conserved Tcp 10 binding domain, which is involved in binding to the protein 4.1R-135 [4]. Later, in a Pakistani family, a deletion of four consecutive nucleotides (TCAG) was identified in exon 11 of $C E N P J$ gene, leading to frameshift and premature termination by a codon $19 \mathrm{bp}$ downstream in the same exon, predicted to add six amino acids downstream of the mutation [59]. More recently, a novel splicing mutation in CENPJ gene [60] has been observed in Seckel syndrome patients. CENPJ is localized at the centrosome during mitosis and it is concentrated at the mitotic spindle poles during pro-metaphase and metaphase $[16,56]$. Cho et al. have observed that depletion of CENPJ disrupts centrosome integrity, and cells lacking CPAP are arrested in mito- sis with multipolar spindles. It has been found that CENPJ depletion by the use of siRNA lead to an increase of multiple spindle poles, mitosis arrest and apoptosis [61]. CENPJ interacts with the N-terminal domain of the p65 subunit (RelA) of NF-kappa B, a transcription factor important for various cellular events such as inflammation, immune response, proliferation and apoptosis [62].

SIL/STIL (MCPH7). The human SCL/TAL1-interrupting locus gene encodes STIL, also referred to as SCL-interrupting locus (SIL). STIL is an immediate early gene that encodes a cytosolic protein of $150 \mathrm{kDa}$. It contains 20 exons and 1287 residues in full-length protein $[2,18,63]$. Two isoforms have been reported. The STIL gene spans 63018 bp with 5225 bp ORF. Sequence analysis of STIL revealed 3 different homozygous protein truncating mutations in affected members of 5 Indian families linked to MCPH7. Heterogeneity analysis of 24 families previously excluded from linkage to the six known MCPH loci suggested linkage of five families $(20.83 \%)$ to the MCPH7 locus. Further, another ascertained family was homozygous for the same mutation as one of the original families [18]. It is also reported that the two $\mathrm{MCPH}$-associated proteins STIL and CPAP interact with each other and are required for procentriole formation, implying a central role of centriole biogenesis in MCPH [64]. Karkera et al. found that the human STIL protein contains a putative nuclear localization signal and a cysteine-terminal domain similar to the C-terminal domain of TGF-beta [63]. $S T I L$ is an early response gene that is ubiquitously expressed in proliferating cells and during early embryonic development $[65,66]$. STIL is expressed throughout the cytosol with increased expression in the perinuclear region that likely plays a role in mitotic entry (cell cycle progression G2-M), apoptosis control and centrosome function [18].

Mutation Continuum of Microcephaly Genes in Pakistan population. Due to high rate of consanguinity $(\sim 61 \%)$ and large family size, Pakistani population has proved to be rich for genetic linkage studies. A total of about 95 families have been reported with mutations in any of microcephaly genes from Pakistan (Table 2). Except one recently discovered locus from India (MCPH7), all other MCPH loci have been reported in Pakistani families. ASPM gene mutations have been found in 83 families with 2 families having compound 
Table 2

Mutations in microcephaly genes (MCPH1, WDR62, CDK5RAP2, and CENPJ) from Pakistani families

\begin{tabular}{c|c|c|c|c}
\hline Gene & Mutation & State of mutation & Present in N of families from Pakistan & Reference \\
\hline MCPH1 & $74 \mathrm{C}-\mathrm{G}$ & Homozygous & Two & {$[15]$} \\
WDR62 & $3232 \mathrm{G}-\mathrm{A}$ & Homozygous & One & Two \\
& $246 \mathrm{~T}-\mathrm{A}$ & Homozygous & One & {$[16,37]$} \\
CDK5RAP2 & IVS26-15A-G & Homozygous & Two & {$[16]$} \\
CENPJ & Homozygous & Homozygous & One & {$[16]$} \\
\hline
\end{tabular}

heterozygous mutations. Two mutations $3978 \mathrm{G} \rightarrow \mathrm{A}$ and 8508delGA were most common, segregating in 18 and 4 families, respectively. CDK5RAP2 gene mutations have been found in three Pakistani families so far, and they are exclusive to Pakistan. One mutation (IVS26$15 \mathrm{~A} \rightarrow \mathrm{G}$ ) was observed in one family while other mutation (Y82X) was present in two families. Two mutations (17delC and 3243delTCAGa) have been found in CENPJ gene segregating in three Pakistani families [14]. In one Pakistani family, linked to MCPH2 locus, a missense mutation $3232 \mathrm{G} \rightarrow$ A (Ala1078Thr) in exon 27 of the WDR62 gene has been detected [8]. Previously the locus was reported in Pakistani families only but the mutations in WDR62 gene have been found in microcephaly patients from other countries as well $[8$, 33, 34].

Mutations in genes encoding not only mitotic and apoptotic proteins but also transcription factors may be responsible for malformative microcephaly syndromes [68]. CASK is a multidomain scaffolding protein that interacts with the transcription factor TBR 1 and regulates expression of genes involved in cortical development. It has been reported that all affected individuals with CASK mutations had congenital or postnatal microcephaly [69]. The common variations in the microcephaly genes do not affect the risk of Alzheimer Disease or that their effect size is small [70]. It was suggested that ASPM and microcephalin have the potential to be biomarkers in ovarian cancer [71].

Conclusion. The proteins encoded by the microcephaly genes are involved in various molecular mechanisms including cell division, cell cycle regulation, appropriate spindle orientation, DNA damage response signaling, microtubule dynamics, etc. Recent functional studies have confirmed the presence of microcephaly proteins at centrosome for at least part of the cell cycle. Therefore, it may be concluded that centrosome is the final integration point for many regulatory pathways affecting prenatal neurogenesis in mammals. Better genotyping, neuro-imaging and neuro-physiological testing, along with constitution of genetically homogeneous groups of patients, would help in establishing exact genotype-phenotype correlation. Mutation screening in microcephaly families is need of the time. It will help in genetic counselling and prenatal diagnosis for microcephaly, and thus in turn may help reducing the incidence of mirocephaly from highly consanguineous population.

\section{C. Шахід, C. Іриад}

Гени мікроцефалії (огляд)

Резюме

В огляді узагальнено дані останніх років з вивчення генів мікроцефалії. Обговорюються результати молекулярно-генетичного дослідження иих генів, зроблено оцінку семи визначених локусів (МСРН1-МСРН7), описано відповідні їм гени і білкові продукти генів, їхня можлива роль у нормальному розвитку мозку, а також мутаиії у цих генах.

Ключові слова: мікроцефалія, локус МСРН, ген МСРН, мутаияя, нейрогенез.

\section{С. Шахид, С. Ириад}

Гены микроцефалии (обзор)

Резюме

В обзоре обобщены данные последних лет по изучению генов микрочефалии. Обсуждаются результаты молекулярно-генетического исследования этих генов, сделана оценка семи определенных локусов (МСРН1-МСРН7), описаны соответствующие им гены и 
белковые продукты генов, их вероятная роль в нормальном развитии мозга, а также мутации в этих генах.

Ключевые слова: микрочефалия, МСРН локус, МСРН ген, мутация, нейрогенез.

\section{REFERENCES}

1. Ashwal S., Michelson D., Plawner L., Dobyns W. B., Quality Standards Subcommittee of the American Academy of Neurology and the Practice Committee of the Child Neurology Society Practice parameter: evaluation of the child with microcephaly (an evidence-based review): report of the Quality Standards Subcommittee of the American Academy of Neurology and the Practice Committee of the Child Neurology Society // Neurology.2009.-73, N 11.-P. 887-897.

2. Kaindl A. M., Passemard S., Kumar P., Kraemerc N., Issa L., Zwirner A., Gerard B., Verloes A., Manig S., Gressens P. Many roads lead to primary autosomal recessive microcephaly // Progr. Neurobiol.-2010.-90, N 3.-P. 363-383.

3. Kim H. T., Lee M. S., Choi J. H., Jung J. Y., Ahn D. G., Yeo S. Y., Choi D. K., Kim C. H. The microcephaly gene aspm is involved in brain development in zebraish // Biochem. Biophys. Res. Commun.-2011.-409, N 4.-P. 640-644.

4. Woods G. C., Bond J., Enard $W$. Autosomal recessive primary microcephaly $(\mathrm{MCPH})$ : a review of clinical, molecular, and evolutionary findings // Am. J. Hum. Genet.-2005.-76, N 5.P. 717-728.

5. Wollnik B. A common mechanism for microcephaly // Nat. Genet.-2010.-42, N 11.-P. 923-924.

6. Desir J., Cassart M., David P., Bogaert P. V., Abramowicz M. Primary microcephaly with ASPM mutation shows simplified cortical gyration with antero-posterior gradient pre- and postnatally // Am. J. Med. Genet.-2008.-146A, N 11.-P. 1439-1443.

7. Thornton G. K., Woods C. G. Primary microcephaly: do all roads lead to Rome? // Trends Genet.-2009.-25, N 11.-P. 501-510.

8. Nicholas A. K., Khurshid M., Desir J., Carvalho O. P., Cox J. J., Thornton G., Kausar R., Ansar M., Ahmad W., Verloes A., Passemard S., Misson J. P., Lindsay S., Gergely F., Dobyns W. B., Roberts E., Abramowicz M., Woods C. G. WDR62 is associated with the spindle pole and is mutated in human microcephaly // Nat. Genet.-2010.-42, N 11.-P. 1010-1014.

9. Sir J. H., Barr A. R., Nicholas A. K., Carvalho O. P., Khurshid M., Sossick A., Reichelt S., D'Santos C. D., Woods C. G., Gergely F. A primary microcephaly protein complex forms a ring around parental centrioles // Nat. Genet.-2011.-43, N 11.-P. 1147-1153.

10. Nicholas A. K., Swanson E. A., Cox J. J., Karbani G., Malik S., Springell K., Hampshire D., Ahmed M., Bond J., Di Benedetto D., Fichera M., Romano C., Dobyns W. B., Woods C. G. The molecular landscape of ASPM mutations in primary microcephaly // J. Med. Genet.-2009.-46, N 4.-P. 249-253.

11. Woods G. C. Human microcephaly // Curr. Opin. Neurobiol.2004.-14, N 1.-P. 112-117.

12. Cox J., Jackson A. P., Bond J., Woods C. G. What primary microcephaly can tell us about brain growth // Trends Mol. Med.2006--12, N 8.-P. 358-366.

13. Montgomery H. S., Mundy N. I. Brain evolution: microcephaly genes weigh in // Curr. Biol.-2010.-20, N 5.-R244-246.

14. Mahmood S., Ahmad W., Hassan M. J. Autosomal recessive primary microcephaly (MCPH): clinical manifestations, genetic heterogeneity and mutation continuum // Orphanet. J. Rare Dis.-2011.-6.-P. 39.

15. Jackson A. P., Eastwood H., Bell S. M., Adu J., Toomes C., Carr I. M., Roberts E., Hampshire D. J., Crow Y. J., Mighell A. J.,
Karbani G., Jafri H., Rashid Y., Mueller R. F., Markham A. F., Woods $C$. G. Identification of microcephalin, a protein implicated in determining the size of the human brain // Am. J. Hum. Genet.-2002.-71, N 1.-P. 136-142.

16. Bond J., Roberts E., Springell K., Lizarraga S. B., Scott S., Higgins J., Hampshire D. J., Morrison E. E., Leal G. F., Silva E. O., Costa S. M. R., Baralle D., Raponi M., Karbani G., Rashid Y., Jafri H., Bennett C., Corry P., Walsh C. A., Woods C. G. A centrosomal mechanism involving CDK5RAP2 and CENPJ controls brain size // Nat. Genet.-2005.-37, N 4.-P. 353-355.

17. Shen J., Eyaid W., Mochida G. H., Al-Moayyad F., Bodell A., Woods C. G., Walsh C. A. ASPM mutations identified in patients with primary microcephaly and seizures // J. Med. Genet.-2005.42, N 9.-P. 725-729.

18. Kumar A., Girimaji S. C., Duvvari M. R., Blanton S. H. Mutations in STIL, encoding a pericentriolar and centrosomal protein, cause primary microcephaly // Am. J. Hum. Genet.-2009.-84, N 2.-P. 286-290.

19. Ponting C., Jackson A. P. Evolution of primary microcephaly genes and the enlargement of primate brains // Curr. Opin. Genet. Dev.-2005.-15, N 3.-P. 241-248.

20. Gruber R., Zhou Z., Sukchev M., Joerss T., Frappart P. O., Wang $Z$. $Q$. MCPH1 regulates the neuroprogenitor division mode by coupling the centrosomal cycle with mitotic entry through the Chk1-Cdc25 pathway // Nat. Cell Biol.-2011.-13, N 11.P. 1325-1334.

21. Trimborn M., Bell S. M., Felix C., Rashid Y., Jafri H., Griffiths P. D., Neumann L. M., Krebs A., Reis A., Sperling K., Neitzel H., Jackson A. P. Mutations in microcephalin cause aberrant regulation of chromosome condensation // Am. J. Hum. Genet.-2004.75, N 2.-P. 261-266.

22. Trimborn M., Richter R., Sternberg N., Gavvovidis I., Schindler D., Jackson A. P., Prott E. C., Sperling K., Gillessen-Kaesbach $G$., Neitzel $H$. The first missense alteration in the $M C P H 1$ gene causes autosomal recessive microcephaly with an extremely mild cellular and clinical phenotype // Hum. Mutat.-2005.-26, N 5.-P. 496.

23. Garshasbi M., Motazacker M. M., Kahrizi K., Behjati F., Abedini S. S., Nieh S. E., Firouzabadi S. G., Becker C., Ruschendorf F., Nurnberg P., Tzschach A., Vazifehmand R., Erdogan F., Ullmann R., Lenzner S., Kuss A. W., Ropers H. H., Najmabadi H. SNP array-based homozygosity mapping reveals $M C P H 1$ deletion in family with autosomal recessive mental retardation and mild microcephaly // Hum. Genet.-2010.-118, N 6.-P. 708-715.

24. Rimol L. M., Agartz I., Djurovic S., Brown A. A., Roddey J. C., Kahler A. K., Mattingsdal M., Athanasiu L., Joyner A. H., Schork N. J., Halgreng E., Sundeth K., Melle I., Dale A. M., Andreassen $O$. A., Alzheimer's Disease Neuroimaging Initiative. Sex-dependent association of common variants of microcephaly genes with brain structure // Proc. Natl Acad. Sci. USA.-2010.-107, N 1.P. 384-388.

25. Alderton G. K., Galbiati L., Griffith E., Surinya K. H., Neitze H., Jackson A. P., Jeggo P. A., O'Driscoll M. Regulation of mitotic entry by microcephalin and its overlap with ATR signalling // Nat. Cell Biol.-2006.-8, N 7.-P. 725-733.

26. Farooq M., Baig S., Tommerup N., Kjaer K. W. Craniosynostosis-microcephaly with chromosomal breakage and other abnormalities is caused by a truncating $\mathrm{MCPH1}$ mutation and is allelic to premature chromosomal condensation syndrome and primary autosomal recessive microcephaly type 1 // Am. J. Med. Genet.2010.-152A, N 2.-P. 495-497.

27. Tang B. L. Molecular genetic determinants of human brain size // Biochem. Biophys. Res. Commun.-2006.-345, N 3.P. 911-916. 
28. Peng G., Yim E. K., Dai H., Jackson A. P., Burgt I., Pan M. R., $H u$ R., Li K., Lin S. Y. BRIT1/MCPH1 links chromatin remodelling to DNA damage response // Nat. Cell Biol.-2009.-11, N 7.P. 865-872.

29. Neitzel H., Neumann L. M., Schindler D., Wirges A., Tonnies H., Trimborn M., Krebsova A., Richter R., Sperling K. Premature chromosome condensation in humans associated with microcephaly and mental retardation: a novel autosomal recessive condition // Am. J. Hum. Genet.-2002.-70, N 4.-P. 1015-1022.

30. Trimborn M., Schindler D., Neitzel H., Hirano T. Misregulated chromosome condensation in $\mathrm{MCPH1}$ primary microcephaly is mediated by condensin II // Cell Cycle.-2006.-5, N 3.-P. 322-326.

31. Wood J. L., Singh N., Mer G., Chen J. MCPH1 functions in an H2AX-dependent but MDC1-independent pathway in response to DNA damage // J. Biol. Chem.-2007.-282, N 48.-P. 3541635423

32. Saadi A., Borck G., Boddaert N., Chekkour M. C., Imessaoudene B., Munnich A., Colleaux L., Chaouch M. Compound heterozygous $A S P M$ mutations associated with microcephaly and simplified cortical gyration in a consanguineous Algerian family // Eur. J. Med. Genet.-2009.-52, N 4.-P. 180-184.

33. Bilguvar K., Ozturk A. K., Louvi A., Kwan K. Y., Choi M., Tatli B., Yalnizoglu D., Tuysuz B., Caglayan A. O., Gokben S., Kaymakcalan H., Barak T., Bakircioglu M., Yasuno K., Ho W., Sanders S., Zhu Y., Yilmaz S., Dincer A., Johnson M. H., Bronen R. A., Kocer N., Per H., Mane S., Pamir M. N., Yalcinkaya C., Kumandas S., Topcu M., Ozmen M., Sestan N., Lifton R. P., State $M$. $W$., Gunel $M$. Whole-exome sequencing identifies recessive WDR62 mutations in severe brain malformations // Nature.2010,-467, N 7312,-P. 207-210.

34. Yu T. W., Mochida G. H., Tischfield D. J., Sgaier S. K., FloresSarnat L., Sergi C. M., Topcu M., McDonald M. T., Barry B. J., Felie J. M., Sunu C., Dobyns W. B., Folkerth R. D., Barkovich A. $J$., Walsh C. A. Mutations in WDR62, encoding a centrosomeassociated protein, cause microcephaly with simplified gyri and abnormal cortical architecture // Nat. Genet.-2010.-42, N 11.P. 1015-1020.

35. Hagemann C., Anacker J., Gerngras S., Kuhnel S., Said H. M., Patel R., Kammerer U., Vordermark D., Roosen K., Vince G. H. Expression analysis of the autosomal recessive primary microcephaly genes $M C P H 1$ (microcephalin) and MCPH5 (ASPM, abnormal spindle-like, microcephaly associated) in human malignant gliomas // Oncol. Rep.-2008.-20, N 2.-P. 301-308.

36. Evans P. D., Vallender E. J., Lahn B. T. Molecular evolution of the brain size regulator genes $C D K 5 R A P 2$ and $C E N P J / /$ Gene.2006.-375.-P. 75-79.

37. Hassan M. J., Khurshid M., Azeem Z., John P., Ali G., Chishti M. S., Ahmad $W$. Previously described sequence variant in CDK5RAP2 gene in a Pakistani family with autosomal recessive primary microcephaly // BMC Med. Genet.-2007.-8.-P. 58.

38. Zhang X., Liu D., Lv S., Wang H., Zhong X., Liu B., Wang B., Liao J., Li J., Pfeifer G. P., Xu X. CDK5RAP2 is required for spindle checkpoint function // Cell Cycle.-2009.-8, N 8.P. 1206-1216.

39. Guernsey D. L., Jiang H., Hussin J., Arnold M., Bouyakdan K., Perry S., Babineau-Sturk T., Beis J., Dumas N., Evans S. C., Ferguson M., Matsuoka M., Macgillivray C., Nightingale M., Patry L., Rideout A. L., Thomas A., Orr A., Hoffmann I., Michaud J. L., Awadalla P., Meek D. C., Ludman M., Samuels M. E. Mutations in centrosomal protein CEP152 in primary microcephaly families linked to MCPH4 // Am. J. Hum. Genet.-2010.-87, N 1.-P. 40-51.

40. Blachon S., Gopalakrishnan J., Omori Y., Polyanovsky A., Church A., Nicastro D., Malicki J., Avidor-Reiss T. Drosophila asterless and vertebrate Cep152 Are orthologs essential for centriole duplication // Genetics.-2008.-180, N 4.-P. 2081-2094.

41. Darvish H., Esmaeeli-Nieh S., Monajemi G. B., Mohseni M., Ghasemi-Firouzabadi S., Abedini S. S., Bahman I., Jamali P., Azimi S., Mojahedi F., Dehghan A., Shafeghati Y., Jankhah A., Falah M., Banavandi M. J., Ghani-Kakhi M., Garshasbi M., Rakhshani F., Naghavi A., Tzschach A., Neitzel H., Ropers H. H., Kuss A. W., Behjati F., Kahrizi K., Najmabadi H. A clinical and molecular genetic study of 112 Iranian families with primary microcephaly // J. Med. Genet.-2010.-47, N 12.-P. 823828.

42. Bond J., Roberts E., Mochida G. H., Hampshire D. J., Scott S., Askham J. M., Springell K., Mahadevan M., Crow Y. J., Markham A. F., Walsh C. A., Woods C. G. ASPM is a major determinant of cerebral cortical size // Nat. Genet.-2002.-32, N 2.P. $316-320$.

43. Bond J., Scott S., Hampshire D. J., Springell K., Corry P., Abramowicz M. J., Mochida G. H., Hennekam R. C., Maher E. R., Fryns J. P., Alswaid A., Jafri H., Rashid Y., Mubaidin A., Walsh C. A., Roberts E., Woods C. G. Protein-truncating mutations in $A S P M$ cause variable reduction in brain size // Am. J. Hum. Genet.-2003.-73, N 5.-P. 1170-1177.

44. Kumar A., Blanton S. H., Babu M., Markandaya M., Girimaji S. $C$. Genetic analysis of primary microcephaly in Indian families: novel ASPM mutations // Clin. Genet.-2004.-66, N 4.-P. 341-348.

45. Pichon B., Vankerckhove S., Bourrouillou G., Duprez L., Abramowicz M. J. A translocation breakpoint disrupts the $A S P M$ gene in a patient with primary microcephaly // Eur. J. Hum. Genet.2004.-12, N 5.-P. 419-421.

46. Saunders R. D., Avides M. C., Howard T., Gonzalez C., Glover D. $M$. The Drosophila gene abnormal spindle encodes a novel microtubule-associated protein that associates with the polar regions of the mitotic spindle // J. Cell Biol.-1997.-137, N 4.P. 881-890.

47. Kouprina N., Pavlicek A., Collins N. K., Nakano M., Noskov V. N., Ohzeki J., Mochida G. H., Risinger J. I., Goldsmith P., Gunsior M., Solomon G., Gersch W., Kim J. H., Barrett J. C., Walsh C. A., Jurka J., Masumoto H., Larionov V. The microcephaly $A S P M$ gene is expressed in proliferating tissues and encodes for a mitotic spindle protein // Hum. Mol. Genet.-2005.-14, N 15.P. 2155-2165.

48. Ponting C. P. A novel domain suggests a ciliary function for $A S P M$, a brain size determining gene // Bioinformatics.2006.-22, N 9.-P. 1031-1035.

49. Pulvers J. N., BrykJ., Fish J. L., Wilsch-Brauninger M., Arai Y., Schreier D., Naumann R., Helppi J., Habermann B., Vogt J., Nitsch R., Toth A., Enard W., Paabo S., Huttnera W. B. Mutations in mouse Aspm (abnormal spindle-like microcephaly associated) cause not only microcephaly but also major defects in the germline // Proc. Natl Acad. Sci. USA-2010.-107, N 38.P. $16595-16600$.

50. Cartegni L., Chew S. L., Krainer A. R. Listening to silence and understanding nonsense: exonic mutations that affect splicing // Nat. Rev. Genet.-2002.-3, N 4.-P. 285-298.

51. Fish J. L., Kosodo Y., Enard W., Paabo S., Huttner W. B. Aspm specifically maintains symmetric proliferative divisions of neuroepithelial cells // Proc. Natl Acad. Sci. USA-2006.-103, N 27.P. 10438-10443.

52. Wallerman O., Van Eeghen A., Ten Kate L. P., Wadelius C. Evidence for a second gene for primary microcephaly at $\mathrm{MCPH} 5$ on chromosome 1 // Hereditas.-2003.-139, N 1.-P. 64-67.

53. Fujimori A., Yaoi T., Ogi H., Wang B., Suetomi K., Sekine E., Yu D., Kato T., Takahashi S., Okayasu R., Itoh K., Fushiki S. Ionizing radiation downregulates $A S P M$, a gene responsible for micro- 
cephaly in humans // Biochem. Biophys. Res. Commun.2008.-369, N 3.-P. 953-957.

54. Zhong X., Liu L., Zhao A., Pfeifer G. P., Xu X. The abnormal spindle-like, microcephaly-associated $(A S P M)$ gene encodes a centrosomal protein // Cell Cycle.-2005.-4, N 9.-P. 1227-1229.

55. Riparbelli M. G., Callaini G., Glover D. M., Avides Mdo. C. A requirement for the Abnormal Spindle protein to organise microtubules of the central spindle for cytokinesis in Drosophila // J. Cell Sci.-2002.-15, Pt 5.-P. 913-922.

56. Hung L. Y., Chen H. L., Chang C. W., Li B. R., Tang T. K. Identification of a novel microtubule-destabilizing motif in CPAP that binds to tubulin heterodimers and inhibits microtubule assembly // Mol. Biol. Cell.-2004.-15, N 6.-P. 2697-2706.

57. Chen C. Y., Olayioye M. A., Lindeman G. J., Tang T. K. CPAP interacts with 14-3-3 in a cell cycle-dependent manner// Biochem. Biophys. Res. Commun.-2006.-342, N 4.-P. 1203-1210.

58. Leal G. F., Roberts E., Silva E. O., Costa S. M., Hampshire D. J., Woods $C$. G. A novel locus for autosomal recessive primary microcephaly (MCPH6) maps to 13q122 // J. Med. Genet.-2003.40, N 7.-P. 540-542.

59. Gul A., Hassan M. J., Hussain S., Raza S. I., Chishti M. S., Ahmad $W$. A novel deletion mutation in $C E N P J$ gene in a Pakistani family with autosomal recessive primary microcephaly // J. Hum. Genet.-2006.-51, N 9.-P. 760-764.

60. Al-Dosari M. S., Shaheen R., Colak D., Alkuraya F. S. Novel CENPJ mutation causes Seckel syndrome // J. Med. Genet.2010.-47, N 6.-P. 411-414.

61. Cho J. H., Chang C. J., Chen C. Y., Tang T. K. Depletion of CPAP by RNAi disrupts centrosome integrity and induces multipolar spindles // Biochem. Biophys. Res. Commun.-2006.-339, N 3.-P. 742-747.

62. Koyanagi M., Hijikata M., Watashi K., Masui O., Shimotohno $K$. Centrosomal P4.1-associated protein is a new member of transcriptional coactivators for nuclear factor-kappa B // J. Biol. Chem.-2005.-280, N 13.-P. 12430-12437.

63. Karkera J. D., Izraeli S., Roessler E., Dutra A., Kirsch I., Muenke $M$. The genomic structure, chromosomal localization, and analysis of SIL as a candidate gene for holoprosencephaly // Cytogenet. Genome Res.-2002.-97, N 1-2.-P. 62-67.

64. Tang C. J., Lin S. Y., Hsu W. B., Lin Y. N., Wu C. T., Lin Y. C., Chang $C . W$., $W u K$. S., Tang T. K. The human microcephaly pro- tein STIL interacts with CPAP and is required for procentriole formation // EMBO J.-2011.-30, N 23.-P. 4790-4804.

65. Pfaff K. L., Straub C. T., Chiang K., Bear D. M., Zhou Y., Zon L. $I$. The zebra fish cassiopeia mutant reveals that SIL is required for mitotic spindle organization // Mol. Cell Biol.-2007.-27, N 16.-P. 5887-5897.

66. Campaner S., Kaldis P., Izraeli S., Kirsch I. R. Sil phosphorylation in a Pin1 binding domain affects the duration of the spindle checkpoint // Mol. Cell Biol.-2005.-25, N 15.-P. 6660-6672.

67. Megraw T. L., Sharkey J. T., Nowakowski R. S. Cdk5rap2 exposes the centrosomal root of microcephaly syndromes // Trends Cell Biol.-2011.-21, N 8.-P. 470-480.

68. Baala L., Briault S., Etchevers H. C., Laumonnier F., Natiq A., Amiel J., Boddaert N., Picard C., Sbiti A., Asermouh A., Attie-Bitach T., Encha-Razavi F., Munnich A., Sefiani A., Lyonnet S. Homozygous silencing of T-box transcription factor EOMES leads to microcephaly with polymicrogyria and corpus callosum agenesis // Nat. Genet.-2007.-39, N 4.-P. 454-456.

69. Najm J., Horn D., Wimplinger I., Golden J. A., Chizhikov V. V., Sudi J., Christian S. L., Ullmann R., Kuechler A., Haas C. A., Flubacher A., Charnas L. R., Uyanik G., Frank U., Klopocki E., Dobyns W. B., Kutsche K. Mutations of CASK cause an X-linked brain malformation phenotype with microcephaly and hypoplasia of the brainstem and cerebellum // Nat. Genet.-2008.-40, N 9.-P. 1065-1067.

70. Erten-Lyons D., Wilmot B., Anur P., McWeeney S. K., Silbert L., Kramer P., Kaye J. Microcephaly genes and risk of late-onset Alzheimer disease // Alzheimer Dis. Assoc. Disord.-2011.-25, N 3.-P. 276-282.

71. Bruning-Richardson A., Bond J., Alsiary R., Richardson J., Cairns D. A., McCormack L., Hutson R., Burns P., Wilkinson N., Hall G. D., Morrison E. E., Bell S. M. ASPM and microcephalin expression in epithelial ovarian cancer correlates with tumour grade and survival // Br. J. Cancer.-2011.-104, N 10.-P. 1602-1610.

72. Chang Y. F., Imam J. S., Wilkinson M. F. The nonsense-mediated decay RNA surveillance pathway // Annu. Rev. Biochem.2007.-76.-P. 51-74. 